\title{
Endogenous endothelins and nitric oxide in hypoxic pulmonary vasoconstriction
}

\author{
I. Hubloue*, D. Biarent*, S. Abdel Kafi*, G. Bejjani*, F. Kerbaul*, R. Naeije*, M. Leeman\#
}

Endogenous endothelins and nitric oxide in hypoxic pulmonary vasoconstriction. I. Hubloue, D. Biarent, S. Abdel Kafi, G. Bejjani, F. Kerbaul, R. Naeije, M. Leeman. (C) ERS Journals Ltd 2003.

ABSTRACT: The effects of endothelin receptor blockade on the pulmonary circulation have been reported variably, possibly in relation to a more or less important associated release of endogenous nitric oxide (NO). The aim of this study was to test whether endothelin antagonism would inhibit hypoxic pulmonary vasoconstriction, and if it would not, then would it do so after NO synthase inhibition.

Hypoxic pulmonary vasoconstriction (HPV) was evaluated in anesthetised dogs by the increase in the mean pulmonary artery pressure $\left(P_{\mathrm{pa}}\right)$ minus occluded $P_{\mathrm{pa}}\left(\boldsymbol{P}_{\mathrm{pao}}\right)$ gradient in response to hypoxia (inspiratory oxygen fraction of 0.1 ) at constant pulmonary blood flow.

Bosentan, an endothelin $A$ and $B$ receptor antagonist, did not affect baseline $P$ pa, $P$ pao or systemic arterial pressure $\left(P_{\text {sa }}\right)$ and did not alter HPV $(n=8)$. The NO synthase inhibitor N $N^{G}$-nitro-L-arginine (L-NA) did not affect baseline $P$ pa and $P$ pao, but increased $P$ sa and enhanced HPV $(n=12)$. The addition of bosentan in these dogs did not affect

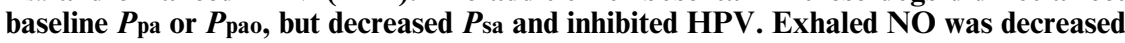
by L-NA and by bosentan and abolished by L-NA+bosentan $(n=9)$.

The authors conclude that endogenous nitric oxide is released by, and opposes the vasoconstricting effects of, endothelins in vivo, reducing systemic blood pressure and limiting hypoxic pulmonary vasoconstriction.

Eur Respir J 2003; 21: 19-24.
*Laboratory of Physiology, Faculty of Medicine, Free University of Brussels, and ${ }^{\#}$ Dept of Intensive Care, Erasme University Hospital, Brussels, Belgium.

Correspondence: M. Leeman, Dept of Intensive Care, Erasme University Hospital, 808, Lennik road, B-1070 Brussels, Belgium.

Fax: 3225556713

E-mail: marc.leeman@ulb.ac.be

\section{Keywords: Endothelins}

hypoxic pulmonary vasoconstriction nitric oxide

pulmonary hypertension

Received: March 282002

Accepted after revision: August 162002

This study was supported by grant $\mathrm{n}^{\circ} 3.4567 .00$ from the Fonds de la Recherche Scientifique Médicale (Belgium).
Endothelins are potent endothelium-derived vasoconstrictors [1]. The endothelin system has been reported to be activated in various types of experimental or clinical pulmonary hypertension [1]. However, whether endogenous endothelins play a role in the control of systemic and pulmonary vascular tone in vivo remains uncertain. Endothelin receptor antagonists have been shown to increase forearm blood flow in humans [2, 3], to reduce brachial artery pressure in patients with essential hypertension [4] and to decrease pulmonary artery pressure in patients with primary pulmonary hypertension $[5,6]$. However, some investigators have been unable to demonstrate pulmonary or systemic vascular effects of these compounds in vivo [7-17]. The failure to show a vasoconstrictor effect of endogenous endothelins appears related, at least in part, to the release of nitric oxide (NO) by the endothelium, which either counteracts the effect and/or inhibits the synthesis of endothelins [16-19].

Endothelins have been hypothesised to play a role in the mediation of hypoxic pulmonary vasoconstriction (HPV). Hypoxia has been reported to increase the level of immunoreactive endothelin-1 in the plasma and of endothelin-1 messenger ribonucleic acid in the lung and right atrium $[12,20]$. However, selective as well as nonselective endothelin receptor blockers have been shown to inhibit HPV in some studies [8-14] but not in others [15, 21-23]. These discrepancies might be explained, at least in part, by variable release of endogenous NO, which has been shown to limit HPV in intact animals [24, 25].

In this study, the effects of endogenous endothelins on hyperoxic and hypoxic vascular tone, with and without $\mathrm{NO}$ synthase inhibition by $\mathrm{N}^{\mathrm{G}}$-nitro-L-arginine (L-NA), were examined. The hypothesis was that endothelin antagonism may inhibit HPV, but if not, would do so after NO synthase inhibition. Because endothelins have opposite vascular effects, possibly mediated by different receptors [1], complete blockade of the actions of endogenous endothelins requires antagonism of both endothelin A and endothelin B receptors, as exerted by the combined nonpeptide blocker bosentan [26]. The effects of hypoxia and drugs on vascular tone were evaluated at constant cardiac output $\left(\mathrm{Q}^{\prime}\right)$ to allow for the discrimination between passive and active tone dependent changes in pulmonary vascular pressure [24, 25].

\section{Methods}

The experiments were conducted in agreement with the Guide for the Care and Use of Laboratory Animals of the US National Institutes of Health and were approved by the Committee on the Care and Use 
of Animals in Research of the Brussels Free University School of Medicine, Brussels, Belgium.

\section{Animal preparation}

Mongrel dogs (16-45 kg) were anaesthetised (pentobarbital $25 \mathrm{mg} \cdot \mathrm{kg}^{-1}$ intravenously followed by $2 \mathrm{mg} \cdot \mathrm{kg}^{-1}$ hourly), paralysed (pancuronium $0.2 \mathrm{mg} \cdot \mathrm{kg}^{-1}$ intravenously followed by $0.2 \mathrm{mg} \cdot \mathrm{kg}^{-1}$ hourly), intubated and ventilated (Elema 900 B Servo ventilator; Siemens, Solna, Sweden) with an inspiratory oxygen fraction $\left(F \mathrm{I}, \mathrm{O}_{2}\right)$ of 0.4 . This higher than normal $F \mathrm{I}, \mathrm{O}_{2}$ was selected to maintain the lungs above the threshold for HPV [25]. Catheters were placed in the jugular vein, in the femoral artery and in the pulmonary artery as described previously [24, 25]. Cardiac output was measured by thermodilution. A balloon catheter was advanced into the inferior vena cava through a right femoral venotomy and a large-bore cannula was inserted into the left femoral artery and vein to act as an arteriovenous bypass. Stepwise inflations of the balloon catheter or opening of the bypass decreased or increased $\mathrm{Q}^{\prime}$, respectively $[24,25]$.

\section{Effect of big endothelin-1 without and with bosentan}

Bosentan (Actelion, Allschwil, Switzerland) was diluted in heated distilled water just before the experiments and administered as an intravenous bolus of $3 \mathrm{mg} \cdot \mathrm{kg}^{-1}$ followed by a constant infusion of $7 \mathrm{mg} \cdot \mathrm{kg}^{-1} \cdot \mathrm{h}^{-1}$ [7]. This dose has been shown to provide optimal endothelin receptor blockade in dogs [7]. The ability of this dose of bosentan to antagonise the effects of big endothelin-1 (Novabiochem, Läufelfingen, Switzerland), the precursor of endothelins, was checked. Big endothelin-1 was diluted in sodium chloride $0.9 \%$ just before the experiments. After two baseline hypoxic challenges $\left(F \mathrm{I}_{2} \mathrm{O}_{2} 0.4-0.1\right.$ for $\left.6 \mathrm{~min}\right)$, the dogs received $1 \mathrm{nmol} \cdot \mathrm{kg}^{-1}$ of big endothelin-1 alone $(n=3)$ or after bosentan $(n=2)$, and two additional hypoxic challenges were performed thereafter. $\mathrm{Q}^{\prime}$ was kept constant using the femoral bypass and the inferior vena caval balloon. Mean pulmonary artery pressure $(P$ pa $)$, occluded $P$ pa $(P$ pao $)$, systemic artery pressure $(P \mathrm{sa}), \mathrm{Q}^{\prime}$ and blood gases were measured after $3 \mathrm{~min}$ stabilisation.

\section{Effect of bosentan}

The response of the $P$ pa $-P$ pao gradient to changes in $F \mathrm{I} \mathrm{O}_{2}(0.4,0.21,0.12,0.1)$ was examined, with $\mathrm{Q}^{\prime} \mathrm{kept}$ constant, before and after bosentan. Each $F \mathrm{I}, \mathrm{O}_{2}$ was maintained for at least 6 min to allow stabilisation.

\section{Effect of bosentan after $N^{G}$-nitro-L-arginine}

Two hypoxic challenges $\left(F \mathrm{I}, \mathrm{O}_{2} \quad 0.4-0.1\right)$ were performed at baseline, after L-NA (Sigma-Aldrich, Bornem, Belgium) $5 \mathrm{mg} \cdot \mathrm{kg}^{-1}$ intravenous bolus followed by a constant infusion of $5 \mathrm{mg} \cdot \mathrm{kg}^{-1} \cdot \mathrm{h}^{-1}$, and again after bosentan. This dose of L-NA has been shown to enhance canine HPV [24, 25]. Q' was kept constant as described above.

Effect of $N^{G}$-nitro-L-arginine and bosentan on exhaled nitric oxide

The concentration of NO was continuously monitored at the tip of the endotracheal tube using a chemiluminescence analyser (Model LR2000; Logan Research, Rochester, UK) [27]. Exhaled NO concentrations were read in triplicate at the maximum value of expired carbon dioxide. These measurements were performed after bosentan alone $(n=4)$, after L-NA $(n=5)$ and after bosentan given after L-NA $(n=4)$.

\section{Analysis of the data}

Results are expressed as means \pm SEM. A two-factor analysis of variance for multiple measurements and modified t-tests were used as appropriate [24, 25, 28]. Values of $\mathrm{p}<0.05$ were considered as significant.

\section{Results}

\section{Effects of big endothelin-1 without and with bosentan}

As designed in the protocol, $Q^{\prime}$ was kept constant in all experiments.

Big endothelin-1 alone. At $F \mathrm{I}, \mathrm{O}_{2}$ 0.4, big endothelin-1 increased $P$ sa from 104 to $132 \mathrm{mmHg}$ and had no effect on $P$ pa $-P$ pao which was $8 \mathrm{mmHg}$ before and after big endothelin-1. The increase in $P$ pa $-P$ pao in response to hypoxia was $2 \mathrm{mmHg}$ before and $4 \mathrm{mmHg}$ after big endothelin-1 $(\mathrm{n}=3)$.

Bosentan followed by big endothelin-1. At $F \mathrm{I}, \mathrm{O}_{2}$ 0.4, bosentan slightly reduced $P_{\text {sa }}$ from 118 to $109 \mathrm{mmHg}$. Big endothelin-1 given after bosentan had no effect on $P$ sa, which remained at $105 \mathrm{mmHg}$. $P$ pa $-P$ pao remained at $8 \mathrm{mmHg}$ at baseline, $8 \mathrm{mmHg}$ after bosentan and $8 \mathrm{mmHg}$ after big endothelin-1. Hypoxia-induced increases in $P$ pa $-P$ pao were $11 \mathrm{mmHg}$ at baseline, $11 \mathrm{mmHg}$ after bosentan and $10 \mathrm{mmHg}$ after big endothelin-1 $(n=2)$.

\section{Effects of bosentan alone}

Hypoxia increased the $P$ pa $-P$ pao gradient measured at constant $\mathrm{Q}^{\prime}$ (table 1 and fig. 1). Administration of bosentan did not affect $P$ pa $-P$ pao in hyperoxia, normoxia and hypoxia (fig. 1). Neither hypoxia nor bosentan significantly affected $P$ sa $($ table 1$)(n=8)$.

\section{Effects of bosentan after $N^{G}$-nitro-L-arginine}

At constant $\mathrm{Q}^{\prime}$, bosentan inhibited the L-NAinduced increase in HPV (fig. 2) $(n=12)$. Bosentan 
Table 1. - Effects of bosentan at different inspiratory oxygen fractions $\left(\mathrm{Fi}, \mathrm{O}_{2}\right)$ in eight dogs

\begin{tabular}{|c|c|c|c|c|c|}
\hline & \multicolumn{4}{|c|}{$\mathrm{Fi}_{\mathrm{i}, \mathrm{O}_{2}}$} & \multirow[t]{2}{*}{ p-value } \\
\hline & 0.4 & 0.21 & 0.12 & 0.1 & \\
\hline \multicolumn{6}{|c|}{$\mathrm{Q}^{\prime} \mathrm{L} \cdot \mathrm{min}^{-1} \cdot \mathrm{m}^{-2}$} \\
\hline Baseline & $4.9 \pm 0.5$ & $4.8 \pm 0.5$ & $4.8 \pm 0.5$ & $4.8 \pm 0.5$ & NS \\
\hline Bosentan & $5.0 \pm 0.5$ & $4.8 \pm 0.5$ & $4.8 \pm 0.5$ & $4.8 \pm 0.5$ & NS \\
\hline \multicolumn{6}{|l|}{$P$ pa $\mathrm{mmHg}$} \\
\hline Baseline & $12 \pm 1$ & $11 \pm 1$ & $13 \pm 1$ & $16 \pm 1$ & $<0.01$ \\
\hline Bosentan & $11 \pm 1$ & $11 \pm 1$ & $13 \pm 1$ & $15 \pm 1$ & $<0.01$ \\
\hline \multicolumn{6}{|l|}{$P$ pao $\mathrm{mmHg}$} \\
\hline Baseline & $3 \pm 1$ & $2 \pm 1$ & $2 \pm 1$ & $2 \pm 1$ & NS \\
\hline Bosentan & $2 \pm 1$ & $2 \pm 1$ & $1 \pm 1$ & $2 \pm 1$ & NS \\
\hline \multicolumn{6}{|l|}{$P$ sa $\mathrm{mmHg}$} \\
\hline Baseline & $109 \pm 10$ & $114 \pm 12$ & $123 \pm 15$ & $122 \pm 17$ & NS \\
\hline $\begin{array}{l}\text { Bosentan } \\
f_{\mathrm{c}} \text { beats } \cdot \mathrm{min}\end{array}$ & $105 \pm 9$ & $104 \pm 14$ & $108 \pm 14$ & $104 \pm 11$ & NS \\
\hline Baseline & $152 \pm 4$ & $152 \pm 7$ & $160 \pm 8$ & $157 \pm 8$ & NS \\
\hline Bosentan & $154 \pm 7$ & $155 \pm 9$ & $166 \pm 7$ & $162 \pm 6$ & NS \\
\hline \multicolumn{6}{|l|}{$\mathrm{pHa}$} \\
\hline Baseline & $7.32 \pm 0.03$ & $7.33 \pm 0.01$ & $7.35 \pm 0.01$ & $7.34 \pm 0.02$ & NS \\
\hline Bosentan & $7.34 \pm 0.01$ & $7.34 \pm 0.02$ & $7.36 \pm 0.02$ & $7.37 \pm 0.02$ & NS \\
\hline \multicolumn{6}{|l|}{$\mathrm{Pa}, \mathrm{O}_{2} \mathrm{mmHg}$} \\
\hline Baseline & $204 \pm 11$ & $99 \pm 5$ & $46 \pm 2$ & $35 \pm 2$ & $<0.01$ \\
\hline Bosentan & $213 \pm 16$ & $98 \pm 8$ & $47 \pm 4$ & $35 \pm 3$ & $<0.01$ \\
\hline \multicolumn{6}{|c|}{$P \mathrm{a}, \mathrm{CO}_{2} \mathrm{mmHg}$} \\
\hline Baseline & $45 \pm 2$ & $41 \pm 2$ & $41 \pm 2$ & $40 \pm 3$ & NS \\
\hline Bosentan & $39 \pm 3$ & $37 \pm 2$ & $37 \pm 3$ & $38 \pm 3$ & NS \\
\hline \multicolumn{6}{|l|}{$P_{\mathrm{v}, \mathrm{O}_{2}} \mathrm{mmHg}$} \\
\hline Baseline & $62 \pm 4$ & $51 \pm 3$ & $32 \pm 2$ & $26 \pm 2$ & $<0.01$ \\
\hline Bosentan & $59 \pm 4$ & $52 \pm 4$ & $34 \pm 4$ & $27 \pm 3$ & $<0.01$ \\
\hline
\end{tabular}

Data are presented as mean \pm SEM. p-value: level of significance of the F-ratio of the analysis of variance; $\mathrm{Q}^{\prime}$ : cardiac index; $P$ pa: mean pulmonary artery pressure; $P$ pao: pulmonary artery occluded pressure; $P_{\text {sa: }}$ mean systemic artery pressure; $f_{\mathrm{c}}$ : cardiac frequency; $\mathrm{pHa}$ : arterial $\mathrm{pH} ; \mathrm{Pa}_{\mathrm{a}} \mathrm{O}_{2}$ : oxygen tension in arterial blood; $\mathrm{Pa}_{\mathrm{a}} \mathrm{CO}_{2}$ : carbon dioxide tension in arterial blood; $P_{\mathrm{v}, \mathrm{O}_{2}}$ : oxygen tension in mixed venous blood.

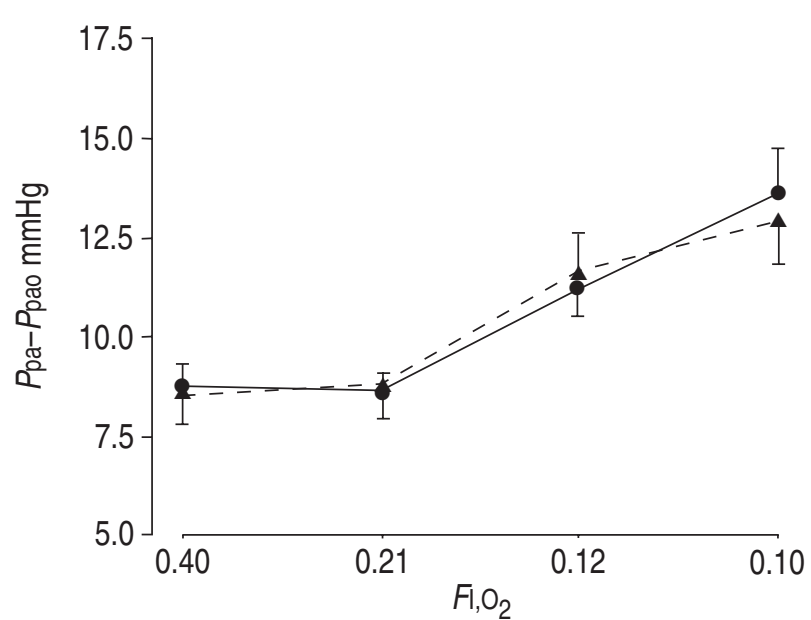

Fig. 1.- Mean pulmonary artery pressure $\left(P_{\text {pa }}\right)$ minus occluded $P$ pa $(P$ pao $)$ at constant cardiac output in eight dogs as the inspiratory oxygen fraction $\left(F \mathrm{I}, \mathrm{O}_{2}\right)$ was decreased from 0.4 to 0.1 , before $(\boldsymbol{O})$ and after $(\boldsymbol{\Delta})$ the administration of bosentan. Data are presented as mean \pm SEM. Bosentan had no effect on hypoxic pulmonary vasoconstriction assessed by constant flow hypoxiainduced increase in $P$ pa- $P$ pao.

also reduced the systemic arterial hypertension induced by L-NA in hyperoxia and in hypoxia (table 2).

\section{Effects on exhaled nitric oxide}

Exhaled NO was $0.96 \pm 0.12$ parts per billion (ppb) in hyperoxia and $1.01 \pm 0.13 \mathrm{ppb}$ in hypoxia ( $\mathrm{p}=\mathrm{NS}$, $\mathrm{n}=9$ ). L-NA decreased exhaled NO to $0.42 \pm 0.16 \mathrm{ppb}$ in hyperoxia and $0.39 \pm 0.17$ in hypoxia $(p<0.01$ compared to baseline at the same $F \mathrm{I}, \mathrm{O}_{2} ; \mathrm{p}=$ NS hyperoxia compared to hypoxia, $\mathrm{n}=5$ ). Bosentan alone decreased exhaled NO to $0.17 \pm 0.05 \mathrm{ppb}$ in hyperoxia and $0.14 \pm 0.07 \mathrm{ppb}$ in hypoxia $(\mathrm{p}<0.01$ compared to baseline at the same $\left.F \mathrm{I}, \mathrm{O}_{2}, \mathrm{n}=4\right)$. L-NA followed by bosentan decreased exhaled $\mathrm{NO}$ to $0.05 \pm 0.03 \mathrm{ppb}$ in hyperoxia and in hypoxia $(\mathrm{p}<0.01$ compared to baseline, $n=4)$.

\section{Discussion}

The present results show that endothelin receptor antagonism by bosentan has no effects on pulmonary or systemic haemodynamics in normoxic nor in hypoxic conditions, but that it inhibits the enhancement of acute HPV and the increase in systemic blood pressure observed after NO synthase inhibition. As bosentan decreased exhaled NO, it appears that endothelins inhibit their own vasoconstricting effect by generating NO. Since a combined endothelin A and $\mathrm{B}$ receptor antagonist were used, the results 


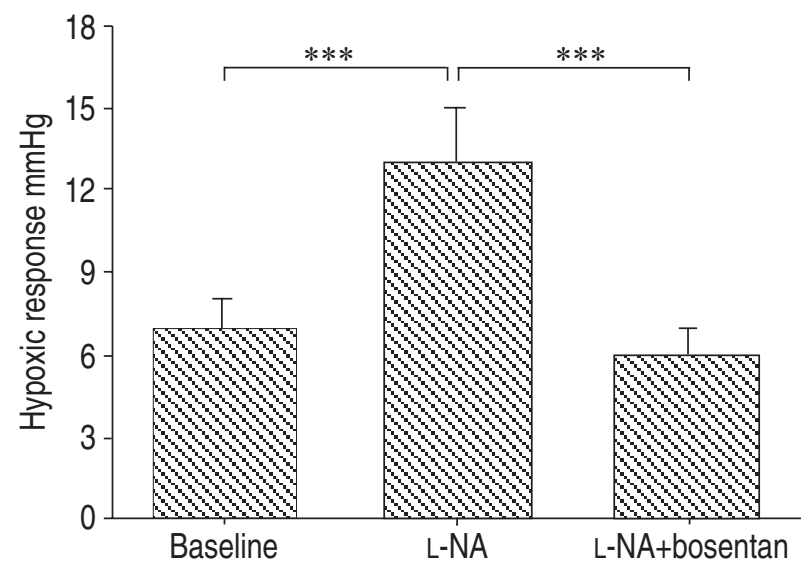

Fig. 2.-Hypoxic response defined as the increase in the gradient between mean pulmonary artery pressure and occluded pulmonary artery pressure measured at constant cardiac output in response to a reduction in the fraction of inspiratory oxygen from 0.4 to 0.1 at baseline, after administration of $\mathrm{N}^{\mathrm{G}}$-nitro-L-arginine (L-NA), and after the addition of bosentan to L-NA in 12 dogs. Data are presented as mean \pm SEM. The L-NA-induced enhancement of hypoxic pulmonary vasoconstriction was reversed by bosentan. $* * *: p<0.001$.

cannot identify the respective effects of these receptors on HPV and exhaled NO.

\section{Pulmonary and systemic vascular tone during hyperoxia and normoxia}

The present results are in agreement with a previous observation that combined endothelin $\mathrm{A}$ and $B$ receptor blockade by bosentan does not affect pulmonary nor systemic haemodynamics in welloxygenated dogs [7], and may suggest that endogenous endothelins do not contribute to basal vascular control. However, an alternative explanation could be that a tonic release of endothelins occurs without demonstrable vasoconstriction because of antagonistic release of $\mathrm{NO}$ or other endogenous vasodilator mediators [16-19]. The current data suggest that this is the case for the systemic but not the pulmonary circulation, since inhibition of NO synthesis did not affect pulmonary vascular resistance but was associated with a bosentan-reversible increase in systemic vascular resistance [17].

\section{Hypoxic pulmonary vasoconstriction}

In the present study, HPV was not affected by bosentan, given at a dose verified to block the vascular effects of the endothelin precursor big endothelin-1. It is of interest that big endothelin-1 alone markedly increased systemic vascular resistance but had no effect on hyperoxic or hypoxic pulmonary vascular resistance. Other authors have also been unable to inhibit HPV with endothelin receptor antagonists, including bosentan [15, 21-23]. Variable results of effects of endothelin receptor blockers on HPV in different experimental models may be explained by variable antagonism of tonic effects of endothelins by circulating or endothelium-derived vasodilating mediators.

\section{Bosentan after nitric oxide inhibition}

The current authors previously reported that inhibition of NO synthase enhances HPV in intact anesthetised dogs [24, 25]. Therefore, the effects of endothelin receptor blockade by bosentan after inhibition of NO synthase were tested. The present results confirm that NO synthase inhibition does not affect pulmonary vascular tone in well oxygenated dogs, but that it increases HPV [24, 25]. They additionally show that NO synthase inhibition unmasks a pulmonary vasoconstrictor effect of endothelins but only in acute hypoxia. This result is in agreement with a previous observation that combined endothelin A and $\mathrm{B}$ receptor antagonism inhibits the pulmonary vasoconstrictor response to L-NA in isolated perfused lungs from rats with chronic hypoxic pulmonary hypertension [19]. The hypertensive foetal pulmonary circulation also dilates in response to the administration of endothelin receptor antagonists [29, 30]. These studies indicate that pulmonary hypertension may

Table 2. - Effects of bosentan after $N^{G}$-nitro-L-arginine (L-NA) in 12 dogs

\begin{tabular}{|c|c|c|c|c|c|c|}
\hline & \multicolumn{2}{|c|}{ Baseline } & \multicolumn{2}{|c|}{ L-NA } & \multicolumn{2}{|c|}{ L-NA+bosentan } \\
\hline & $F_{\mathrm{i}, \mathrm{O}_{2}} 0.4$ & $F \mathrm{i}, \mathrm{O}_{2} \quad 0.1$ & $F_{\mathrm{i}, \mathrm{O}_{2}} 0.4$ & $F_{\mathrm{i}, \mathrm{O}_{2}} 0.1$ & $F_{\mathrm{i}, \mathrm{O}_{2}} 0.4$ & $F \mathrm{i}, \mathrm{O}_{2} \quad 0.1$ \\
\hline $\mathrm{Q}^{\prime} \mathrm{L} \cdot \mathrm{min}^{-1} \cdot \mathrm{m}^{-2}$ & $3.3 \pm 0.3$ & $3.4 \pm 0.3$ & $3.2 \pm 0.3$ & $3.2 \pm 0.3$ & $3.1 \pm 0.3$ & $3.3 \pm 0.3$ \\
\hline$P$ pa $\mathrm{mmHg}$ & $12 \pm 1$ & $18 \pm 2 *$ & $19 \pm 2$ & $27 \pm 3 *$ & $18 \pm 2^{\circ}$ & $22 \pm 3^{\#}$ \\
\hline$P$ pao $\mathrm{mmHg}$ & $4 \pm 1$ & $3 \pm 1$ & $10 \pm 2$ & $6 \pm 1$ & $8 \pm 1^{\#, 9}$ & $5 \pm 1$ \\
\hline$P_{\text {sa }} \mathrm{mmHg}$ & $113 \pm 7$ & $109 \pm 7$ & $144 \pm 8$ & $144 \pm 7^{\bullet}$ & $125 \pm 7^{\#, \oplus}$ & $130 \pm 8^{\#, \oplus}$ \\
\hline$f_{\mathrm{c}}$ beats $\cdot \mathrm{min}^{-1}$ & $149 \pm 8$ & $157 \pm 8$ & $115 \pm 6^{\pi}$ & $145 \pm 8$ & $121 \pm 7^{\bullet}$ & $145 \pm 8$ \\
\hline $\mathrm{pHa}$ & $7.33 \pm 0.01$ & $7.35 \pm 0.01$ & $7.36 \pm 0.01$ & $7.37 \pm 0.01$ & $7.37 \pm 0.01$ & $7.39 \pm 0.02$ \\
\hline $\mathrm{Pa}_{2} \mathrm{O}_{2} \mathrm{mmHg}$ & $195 \pm 12$ & $36 \pm 1 *$ & $201 \pm 7$ & $35 \pm 1 *$ & $160 \pm 14^{\#, \oplus}$ & $32 \pm 2 *$ \\
\hline $\mathrm{Pa}_{\mathrm{a}, \mathrm{CO}_{2} \mathrm{mmHg}}$ & $37 \pm 1$ & $33 \pm 1 *$ & $35 \pm 1$ & $34 \pm 1$ & $34 \pm 1$ & $33 \pm 2$ \\
\hline$P_{\mathrm{v}, \mathrm{O}_{2}} \mathrm{mmHg}$ & $51 \pm 2$ & $24 \pm 2 *$ & $46 \pm 1$ & $22 \pm 2 *$ & $43 \pm 3^{\bullet}$ & $22 \pm 1^{*}$ \\
\hline
\end{tabular}

Data are presented as mean \pm SEM. $F \mathrm{I}_{1} \mathrm{O}_{2}$ : inspiratory oxygen fraction; $\mathrm{Q}^{\prime}$ : cardiac index; $P$ pa: mean pulmonary artery pressure; $P$ pao: pulmonary artery occluded pressure; $P$ sa: mean systemic artery pressure; $f$ c: cardiac frequency; $\mathrm{pHa}$ : arterial $\mathrm{pH} ; P_{\mathrm{a}}, \mathrm{O}_{2}$ : oxygen tension in arterial blood; $P_{\mathrm{a}}, \mathrm{CO}_{2}$ : carbon dioxide tension in arterial blood; $P_{\mathrm{v}}, \mathrm{O}_{2}$ : oxygen tension in mixed venous blood. *: $\mathrm{p}<0.05$ compared with $F \mathrm{I}, \mathrm{O}_{2}$ 0.4, same drug condition; ${ }^{*}: \mathrm{p}<0.05$ compared with L-NA, same $F \mathrm{I}, \mathrm{O}_{2} ;{ }^{\uparrow}: \mathrm{p}<0.05$ compared with baseline, same $\mathrm{FI}, \mathrm{O}_{2}$. 
result from an imbalance of endothelin-1 receptor activation favouring pulmonary vasoconstriction [29], or from a combination of enhanced endothelin A receptor-mediated vasoconstriction together with a decreased NO synthase activity [30].

In the present study, bosentan reduced L-NAinduced systemic hypertension. In anesthetised rats, mixed endothelin A and endothelin B receptor antagonism and selective endothelin A receptor antagonism did not affect $P_{\text {sa }}$ when given alone, but decreased it after NO synthase inhibition [16, 17]. Blockade of NO synthase also increased the plasma levels of endothelin-1 [17]. Compared to normotensive controls, hypertensive patients had larger vasodilation in response to endothelin antagonism and smaller vasoconstriction in response to NO synthase inhibition, both responses being inversely correlated [2]. In accordance with these results, the present data suggest that the systemic hypertensive effect of NO synthase inhibition could be endothelin-mediated.

\section{Exhaled nitric oxide}

As expected, a decrease in exhaled NO was observed after NO synthase inhibition. The current results additionally show, for the first time, that bosentan also reduces exhaled NO. This observation suggests that the vasoconstrictive effects of endothelins are self-limited by an endothelin-induced synthesis of endogenous NO. Although it is generally proposed that endothelial NO synthesis is related to endothelin $B$ receptor stimulation $[1,31,32]$, a recent study shows that activation of endothelin $A$ receptors also can enhance NO production in the vasculature [33]. Patients with acute respiratory distress syndrome have arterial hypoxaemia partially due to inefficient HPV, possibly related to the release of NO [34]. The current results show that bosentan does not inhibit HPV and decreases NO release. It could be speculated that bosentan might be given to reduce pulmonary hypertension in patients with ventilation-to-perfusion impairment, without further deteriorating gas exchange, as usually observed after systemic administration of vasodilators. This hypothesis could be tested in experimental models of lung injury.

\section{Clinical relevance and conclusions}

The current authors propose that endothelins stimulate nitric oxide production in pulmonary vessels, which counteracts their own constricting effect, and that the vasoconstricting action of endothelins can appear only when endogenous nitric oxide synthesis is deficient. The present results are in keeping with the concept that increased pulmonary vascular tone may result from an imbalance between the antagonistic effects of nitric oxide and endothelins, and that pharmacological manipulation of this imbalance offers therapeutic possibilities in pulmonary hypertension. The lungs of patients with severe pulmonary hypertension show a reduced expression of endothelial nitric oxide synthase [35] and an increased expression of endothelin-1 [36]. Endothelin receptor antagonism with bosentan has been reported recently to decrease pulmonary vascular resistance and to improve functional class and exercise capacity in patients with primary pulmonary hypertension $[5,6]$.

\footnotetext{
Acknowledgements. The authors would like to thank M. Clozel (Actelion, Allschwil, Switzerland) for the generous gift of bosentan. The expert technical assistance of P. Jespers, M-T. Gautier, A. Van Muylem and V. Martinet was greatly appreciated.
}

\section{References}

1. Michael JR, Markewitz BA. Endothelins and the lung. Am J Respir Crit Care Med 1996; 154: 555-581.

2. Taddei S, Virdis A, Ghiadoni L, Sudano I, Notari M, Salvetti A. Vasoconstriction to endogenous endothelin-1 is increased in the peripheral circulation of patients with essential hypertension. Circulation 1999; 100: 1680-1683.

3. Verhaar MC, Strachan FE, Newby DE, et al. Endothelin-A receptor antagonist-mediated vasodilatation is attenuated by inhibition of nitric oxide synthesis and by endothelin B receptor blockade. Circulation 1998; 97: 752-756.

4. Krum H, Viskoper RJ, Lacourciere Y, Budde M, Charlon $\mathrm{V}$, for the Bosentan Hypertension Investigators. The effects of endothelin-receptor antagonist, bosentan, on blood pressure in patients with arterial hypertension. $N$ Engl J Med 1998; 338: 784-790.

5. Rubin LJ, Badesch DB, Barst RJ, et al. Bosentan therapy for pulmonary arterial hypertension. $N$ Engl $J$ Med 2002; 346: 896-903.

6. Channick RN, Simmoneau G, Sitbon O, et al. Effects of the dual endothelin-receptor antagonist bosentan in patients with pulmonary hypertension: a randomised placebo-controlled study. Lancet 2001; 358: 1119 1123.

7. Teerlink JR, Carteaux JP, Sprecher U, Löffler BM, Clozel M, Clozel JP. Role of endogenous endothelin in normal hemodynamic status of anesthetized dogs. $\mathrm{Am}$ J Physiol 1995; 268: H432-H440.

8. Sato K, Morio Y, Morris KG, Rodman DM, McMurtry IF. Mechanism of hypoxic pulmonary vasoconstriction involves endothelin A receptormediated inhibition of KATP channel. Am J Physiol 2000; 278: L434-L442.

9. Holm P, Liska J, Franco-Cereceda A. The endothelin A receptor antagonist, BMS-182874, reduces acute hypoxic pulmonary hypertension in pigs in vivo. Cardiovasc Res 1998; 37: 765-771.

10. Willette RN, Ohlstein EH, Mitchell MP, et al. Nonpeptide endothelin receptor antagonists. VIII: attenuation of acute hypoxia-induced pulmonary hypertension in the dog. J Pharmacol Exp Ther 1997; 280: 695-701.

11. Chen SJ, Chen YF, Meng QC, Durand J, Dicarlo VS, Oparil S. Endothelin-receptor antagonist bosentan prevents and reverses hypoxic pulmonary hypertension in rats. $J$ Appl Physiol 1995; 79: 2122-2131.

12. Oparil S, Chen SJ, Meng QC, Elton TS, Yano M, Chen YF. Endothelin-A receptor antagonist prevents 
acute hypoxia-induced pulmonary hypertension in the rat. Am J Physiol 1995; 268: L95-L100.

13. Wang Y, Coe Y, Toyoda O, Coceani F. Involvement of endothelin-1 in hypoxic pulmonary vasoconstriction in the lamb. J Physiol 1995; 482: 421-434.

14. Bonvallet ST, Zamora MR, Hasunuma $\mathrm{K}$, et al. BQ123, an ETA-receptor antagonist, attenuates hypoxic pulmonary hypertension in rats. $\mathrm{Am}$ J Physiol 1994; 266: H1327-H1331.

15. Wong J, Vanderford PA, Winters JW, Chang R, Soifer SJ, Fineman JR. Endothelin-1 does not mediate acute hypoxic pulmonary vasoconstriction in the intact newborn lamb. J Cardiovasc Pharmacol 1993; 22: S262-S266.

16. Banting JD, Friberg P, Adams MA. Acute hypertension after nitric oxide synthase inhibition is mediated primarily by increased endothelin vasoconstriction. J Hypertens 1996; 14: 975-981.

17. Richard V, Hogie M, Clozel M, Löffler BM, Thuillez C. In vivo evidence of an endothelin-induced vasopressor tone after inhibition of nitric oxide synthesis in rats. Circulation 1995; 91: 771-775.

18. Kourembanas S, McQuillan LP, Leung GK, Faller DV. Nitric oxide regulates the expression of vasoconstrictors and growth factors by vascular endothelium under both normoxia and hypoxia. J Clin Invest 1993; 92: 99-104.

19. Muramatsu M, Rodman DM, Oka M, McMurtry IF. Endothelin-1 mediates nitro-L-arginine vasoconstriction of hypertensive rat lungs. Am J Physiol 1997; 272: L807-L812.

20. Elton TS, Oparil S, Taylor GR, et al. Normobaric hypoxia stimulates endothelin-1 gene expression in the rat. Am J Physiol 1992; 263: R1260-R1264.

21. Lazor R, Feihl F, Waeber B, Kucera P, Perret C. Endothelin-1 does not mediate the endotheliumdependent hypoxic contractions of small pulmonary arteries in rats. Chest 1996; 110: 189-197.

22. Takeoka M, Ishizaki T, Sakai A, et al. Effects of BQ-123 on vasoconstriction as a result of either hypoxia or endothelin-1 in perfused rat lungs. Acta Physiol Scand 1995; 155: 53-60.

23. Douglas SA, Vickery-Clark LM, Ohlstein EH. Endothelin-1 does not mediate hypoxic vasoconstriction in canine isolated blood vessels: effect of BQ-123. Br J Pharmacol 1993; 108: 418-421.

24. Leeman M, Zegers de Beyl V, Biarent D, Maggiorini $\mathrm{M}$, Mélot $\mathrm{C}$, Naeije R. Inhibition of cyclooxygenase and nitric oxide synthase in hypoxic vasoconstriction and oleic acid-induced lung injury. Am J Respir Crit Care Med 1999; 159: 1383-1390.

25. Leeman M, Zegers de Beyl V, Delcroix M, Naeije R. Effects of endogenous nitric oxide on pulmonary vascular tone in intact dogs. Am J Physiol 1994; 266: H2343-H2347.

26. Clozel M, Breu V, Gray GA, et al. Pharmacological characterization of bosentan, a new potent orally active nonpeptide endothelin receptor antagonist. J Pharmacol Exp Ther 1994; 270: 228-235.

27. Gabbay E, Fischer AJ, Small T, Leonard AJ, Corris PA. Exhaled single-breath nitric oxide measurements are reproducible, repeatable and reflect levels of nitric oxide found in the lower airways. Eur Respir J 1998; 11: 467-472.

28. Winer BJ. Statistical Principles in Experimental Design. New York, McGraw-Hill, 1991.

29. Thebaud B, de Lagausie P, Forgues D, Aigrain Y, Mercier JC, Dinh-Xuan AT. Endothelin A receptor blockade and endothelin $\mathrm{B}$ receptor stimulation in experimental congenital diaphragmatic hernia. Am J Physiol 2000; 278: L923-L932.

30. Ovadia B, Bekker JM, Fitzgerald RK, et al. Nitric oxide-endothelin-1 interactions after acute ductal constriction in fetal lambs. Am J Physiol 2002; 282: H862-H871.

31. Ivy D, McMurtry IF, Yanagisawa M, et al. Endothelin B receptor deficiency potentiates endothelin-1 and hypoxic pulmonary vasoconstriction. Am $J$ Physiol 2001; 280: L1040-L1048.

32. Sato K, Rodman DM, McMurtry IF. Hypoxia inhibits increased endothelin B receptor-mediated NO synthesis in hypertensive rat lungs. Am J Physiol 1999; 276: L571-L581.

33. Fujii Y, Magder S, Cernacek P, Goldberg P, Guo Y, Hussain SNA. Endothelin receptor blockade attenuates lipopolysaccharide-induced pulmonary nitric oxide production. Am J Respir Crit Care Med 2000; 161: 982-989.

34. Leeman M, Zegers de Beyl V, Gilbert E, Mélot C, Naeije R. Is nitric oxide released in oleic acid lung injury? J Appl Physiol 1993; 74: 650-654.

35. Giaid A, Saleh D. Reduced expression of endothelial nitric oxide synthase in the lungs of patients with pulmonary hypertension. N Engl J Med 1995; 333: 214-221.

36. Giaid A, Yanagisawa M, Langleben D, et al. Expression of endothelin-1 in the lungs of patients with pulmonary hypertension. N Engl J Med 1993; 328: 1732-1739. 